\title{
Federal Homogeneity from the Bottom Up: Provincial Shaping of National HIV/AIDS Policy in South Africa
}

\author{
Nico Steytler \\ University of the Western Cape
}

\begin{abstract}
Federal homogeneity is not always imposed from the center; subnational units can and do influence national policy from the bottom up by developing innovative policies. In South Africa, provincial policies in the area of HIV/AIDS shaped national policies within the context of the overarching normative structure of the national Bill of Rights. The conditions under which this happened were (I) constitutional space for a province to develop an innovative policy and practice, (2) the necessary political will to exploit the constitutional space, and (3) the judicial and political impact of a province's innovative policy on the national policy. While provincial policy informed the court decision, it also furthered the political debate nationally. Finally, intergovernmental competition played an important role in countering the monopolistic tendency that can be produced by cooperative government.
\end{abstract}

The focus of uniform policymaking in federal systems is usually on enforcing homogeneity on units within a federation, based often on the implicit premise that the center is "right," enlightened, or modern and that one or more of the constituent units are "wrong." Subnational units are perceived as pandering to local interests that may be backward, out of step with the national normative framework, or not sympathetic to national interests. The question is then the extent of the units' right to be "wrong" or out of line. Questions of democracy, autonomy, and the overall normative framework of a federal system are thus pertinent.

The center has a number of devices that it can use to effect homogeneity from the top down, such as the uniform set of norms enshrined in a bill of rights. A bill of rights with a focus on individual rights holders is not concerned with the functional division of power. ${ }^{1}$ Other devices include financial incentives deployed through a variety of conditional grants. There may be also overriding supervisory powers in hybrid-federal countries. For example, in South Africa, national legislation prevails over provincial laws on matters falling even within the provinces' exclusive jurisdiction if the national legislation is necessary, inter alia, to maintain national security, economic unity, and essential national standards. ${ }^{2}$ A commitment to the

AUTHOR'S NOTE: This is a revised version of a paper presented at the Annual Meeting of the International Association of Centers for Federal Studies, Institute of Federalism, University of Innsbruck, Austria, 13-17 November 2002. I wish to thank John Kincaid and Anneke Meerkotter for their helpful comments.

'Luan-Vu N Tran, Human Rights and Federalism: A Comparative Study of Freedom, Democracy and Cultural Diversity (The Hague/Boston/London: Martinus Nijhoff, 2000), p. 183.

"See Nico Steytler "Concurrency and Co-operative Government: the Law and Practice in South Africa," SA Public Law 16:2 (2001): 241-254.

(c) Publius: The Journal of Federalism 33:1 (Winter 2003) 
principle of cooperative government and a dominant national government may also ensure that national policy reaches the provinces through intergovernmental relations structures. Where intergovernmental relations are played out in the shadow of strong political-party discipline, as is the case in South Africa, homogeneity is the likely outcome.

The issue can also be turned around, however. What if the center is "wrong" and one or more of the units are "right"? How can the units influence the national government to change a policy that is perceived to be wrong-headed? Can homogeneity be effected from the bottom up? This is an important question because one of the arguments for decentralization of power is the value of innovation through experimentation carried out by constituent units. Moreover, if the national policy is perceived to be wrong, and if it applies to constituent units to their detriment, they have every incentive to challenge it.

That subnational units can and do influence national policy has been a recurring phenomenon in federal systems. Innovative policies and practices in one subnational unit have been replicated in others units as well as adopted by the center. In the United States, the famous statement of Justice Louis Brandeis in New State Ice Co. v. Liebmann is seen to capture the essence of this virtue of federalism: "It is one of the happy incidents of the federal system that a single courageous state may, if its citizens choose, serve as a laboratory, and try novel social and economic experiments without risk to the rest of the country."

While it may be questioned whether a federal system is a necessary condition for such experimentation ${ }^{4}$ (central governments, after all, often engage in pilot projects before rolling out a national policy), competition between the center and subnational units on matters of policy serves other core purposes of a federal system as well. John Kincaid has argued that competition between the center and the states, referred to as intergovernmental or vertical competition, is an essential part of a federal democracy. ${ }^{5}$ Writing in the context of the prevailing model of cooperative federalism, he points out that the consequences of this model have been the centralization of power. Intergovernmental competition becomes then necessary to prevent the rise of monopoly government which will have no incentive to cooperate with subnational units. Competition, therefore, by restraining the center's "monopolistic impulses," ${ }^{16}$ creates the conditions conducive to cooperation and coordination. ${ }^{\text {? }}$

3985 U.S. 262,311 (1932)

"G. Alan Tarr "Laboratories of Democracy? Brandeis, Federalism, and Scientific Management," Publius: The Journal of Federalism 31 (Winter 2001): 37, 46.

5ohn Kincaid "The Competitive Challenge to Cooperative Federalism: A Theory of Federal Democracy," Competition Among States and Local Governments: Efficiency and Equity in American Federalism, eds. Daphne A. Kenyon and John Kincaid (Washington, DC: Urban Institute Press, 1991), pp. 87-114.

${ }^{6} \mathrm{Kincaid}$, "The Competitive Challenge to Cooperative Federalism," p. 91.

'Ibid., 112 
This essay addresses how constituent units in South Africa's decentralized system of government, the provinces, operating within a constitutionally mandated system of cooperative government, ${ }^{8}$ can influence and shape national policy, and, in the process, limit the "monopolistic impulses" of the national government. This occurred recently in the area of the national government's policy on the combating of the HIV/AIDS pandemic in South Africa. The political process of intergovernmental competition played itself out within the context of the overarching normative structure of the Bill of Rights and its enforcement by the courts. The essay, then, explores how this case study may shed light on the conditions under which provinces may contribute to the shaping of national policy from the bottom up.

\section{THE NATIONAL HIV/AIDS POLICY}

Health services are a concurrent competence of both the provinces and the national government in South Africa. ${ }^{9}$ Health services, along with social welfare and education, constitute the bulk of provincial expenditure. All hospitals fall under provincial control, while the national Department of Health is mainly concerned with policy. Formally, national policy is developed in consultation with the provinces through regular meetings of the national Minister of Health and the provincial Members of the Executive Committee (MECs) responsible for health, in an informal intergovernmental relations structure called a MinMEC. Not unlike health policy in federal countries, ${ }^{10}$ the national department dominates this process.

One such policy has been the national government's approach to combating HIV/AIDS. HIV/AIDS is taking on pandemic proportions in South Africa. It is calculated that South Africa has the highest number of people in the world living with HIV/AIDS; the estimations range from between 4.2 million to 6 million out of a population of 40 million. Studies show that 24 percent of pregnant women are HIV-positive. Consequently, around 70,000 to 100,000 babies are being born HIV-positive each year. With an infection rate in excess of 10 percent, HIV/AIDS is the main cause of death in South Africa, with life expectancy predicted to drop in 2010 to 45 years from the present 70 years. The Constitutional Court has described this pandemic as the "the greatest threat to public health in our country."11

HIV/AIDS and its treatment have been contested policy terrain. Part of the debate has been generated by the so-called "dissident" scientists who believe that there is no link between the HIV virus and AIDS and, hence, that the treatment of AIDS with anti-retroviral drugs is wasteful and dangerous because of their highly toxic side-effects. They acknowledge

"See Richard Simeon and Christina Murray, "Multi-Sphere Governance in South Africa: An Interim Assessment," Publius: The Journal of Federalism 31 (Fall 2001): 65-92.

${ }^{9}$ Schedule 4A Constitution of 1996

${ }^{10}$ Keith G. Banting and Stann Corbett, Healh Policy and Federalism: A Comparative Perspective on MultiLevel Governance, eds. Keith G. Banting and Stann Corbett (Montreal and Kingston: McGill-Queen's University Press), p. 16

"Minister of Health and Others $v$. Treatment Action Campaign and Others (1), 2002 (10) BCLR 1033 (CC) para 99 (referred to as the TAC Constitutional Court case). 
that people die of AIDS-the breakdown of the immune system-but they argue that death is caused in the developing world by poverty, malnutrition, and poor living standards. President Thabo Mbeki questioned the orthodox view that HIV caused AIDS, and in May 2000, he convened an AIDS advisory panel, consisting of both orthodox and "dissident" scientists, and charged it with the task of explaining how the disease affected a vast African heterosexual population. As was predicted from the outset, the panel reached no agreement on the cause or treatment of AIDS. However, the president's views on HIV/AIDS and the pharmaceutical companies' role in exploiting the epidemic ${ }^{12}$ made international news headlines until Mbeki publicly withdrew from the debate.

Although "dissident" views on HIV/AIDS were not necessarily held by the national Department of Health, skepticism about the usefulness of antiretroviral drugs and caution about their safety pervaded national health policy in 2001. With health services being a concurrent national-provincial competence, the application of the national HIV/AIDS policy by the provinces was voluntary. It was applied in the provinces governed by the African National Congress (ANC) as well as in KwaZulu-Natal. This province was then governed by an Inkatha Freedom Party (IFP)-ANC coalition with an ANC member responsible for health. The only province that did not apply the national policy was the Western Cape, then governed by the Democratic Alliance (DA). ${ }^{18}$

The substance of the national policy was that anti-retroviral drugs were not to be provided at government hospitals, all of which are administered by the provinces. Two policies attracted particular attention. The first was that the drug AZT-the best-known anti-retroviral drug-could not be provided even to rape survivors, although this therapy was available and widely used in private hospitals and even in government hospitals for medical workers coming in contact with HIV-infected blood through needle-stick injuries. The horror of this policy came to the fore when, in a Northern Cape hospital, a nine-month-old rape survivor was administered the drug, the responsible doctor was reprimanded by the provincial MEC for health for breaching the policy. ${ }^{14}$ In Mpumalanga province, the MEC of health refused to allow an NGO to provide anti-retroviral drugs for rape victims and fired the hospital superintendent for allowing it. ${ }^{15}$

The second policy related to the anti-retroviral drug called Nevirapine, which if provided to HIV-positive pregnant women and their new-born babies, reduces the mother-to-child transmission of the virus by 50 percent.

${ }^{12}$ See, for example, exchange of letters between Mbeki and Tony Leon, the leader of the Opposition, published in Sunday Times, 9 July 2000, p. 14

${ }^{13}$ With the disintegration of the DA towards the end of 2001 , one of the partners, the New National Party (NNP), formed an alliance with the ANC in a deal that gave the NNP the premiership of the province and the ANC the mayorship of the city of Cape Town. The provincial HIV/AIDS policy did not change with the change in government.

1+"State fury over AZT for raped baby," Mail $\&$ Guardian, 11-17 January 2002, p. 3.

${ }^{15}$ "Provinces stonewall action," Mail Eं Guardian, 20-26 September 2002, p. 2. 
Although Nevirapine was the drug of choice, the national government and the nine provinces endorsed in 2001 at a MinMEC meeting the national policy in terms of which two research sites to test Nevirapine would be established in each of the nine provinces for a period of two years. ${ }^{16}$

The aim of the policy was that, on the basis of the test results, a decision would then be made whether to make the drug available in all provincial hospitals. The national Department of Health had concerns about the safety and efficacy of the drug, especially because the side effects of the drug were not known. The management of the program, including counseling and the provision of formula milk, would also be studied. The result was that doctors at hospitals other than the pilot sites could not prescribe Nevirapine even though it had been offered for free by the pharmaceutical companies. The pilot sites, when operating, could reach only 10 percent of the population. ${ }^{17}$

Although the Western Cape agreed to the conduct of the research, it refused to limit the provision of the drug to two sites. Western Cape health officials argued that this national policy flew in the face of medical evidence that Nevirapine is one of the best and cheapest methods of preventing the transmission of the HIV virus. The South African Medicines Control Council registered it conditionally, and the World Health Organization recommended its use if the benefits and risks are weighed up. The drug was indeed available and used in private hospitals. Significantly, being governed at the time by an opposition party, the DA, the leader of which clashed on numerous occasions with the national government on its HIV/ AIDS policy, the province was not legally bound to follow the policy of the national Department of Health and could chart its own course.

\section{THE RIGHT TO HEALTH-CARE SERVICES AND ACTIVE CIVIL SOCIETY}

South Africa boasts of one of the most progressive Bill of Rights in the world, in part because it includes a string of socioeconomic rights. These include the right of everyone to have access to adequate housing, ${ }^{18}$ sufficient food and water, social security and, importantly, "health care services, including reproductive health care." ${ }^{19}$ These rights are heavily qualified; the government need only "take reasonable legislative and other measures, within its available resources, to achieve the progressive realization of each of these rights." 20 Despite these qualifications, the Constitutional Court has been willing to give effect to them. In a significant decision in 2000 ,

\footnotetext{
${ }^{16}$ Protocol for providing a comprehensive package of care for the prevention of mother to child transmission of HIV in South Africa, April 2001, quoted in TAC Constitutional Court judgment, para. 16.

${ }^{17}$ Treatment Action Campaign and Others $v$. Minister of Health and Others, 2002 (4) BLCR 356 (T) 360 (referred to the TAC High Court case)

${ }^{18}$ Section 26 Constitution of 1996.

${ }^{19}$ Section 27 Constitution of 1996.

"Section 27(2) Constitution of 1996. See, generally, Sandra Liebenberg, "Socio-economic Rights," Constitutional Law of South Africa, eds. Mathew Chaskalson, et al. (Cape Town: Juta, 2000); Johan de Waal et al., The Bill of Rights Handbook, 3rd ed. (Cape Town: Juta, 2000), p. 397 eff.
} 
the Court held that the national, provincial, and local governments failed to give effect to the right to housing by not having an emergency policy in place to take care of homeless people in desperate circumstances. ${ }^{21}$ In practice, the Court's ruling meant that while a claimant was not entitled to a house, he or she had a right to a reasonable government policy, and it was the reasonableness of the policy that the Court reviewed in this case.

There are pockets of well-organized civil society in South Africa. The Treatment Action Campaign (TAC), for example, is a consortium of AIDS activists that campaigned against the two policies of the government-refusal to provide AZT for rape victims and to provide Nevirapine for all HIV-positive women and their new-born babies. The Treatment Action Campaign was not alone in its advocacy; the major labor union movement, Cosatu, and even the SA Communist Party voiced concern about the government's policy.

The TAC instituted proceedings in the Pretoria High Court in August 2001 seeking a court order against the national Department of Health and the nine provincial health departments in an effort to compel them (1) to provide Nevirapine where the provincial hospitals had the capacity to do so, and (2) to plan a comprehensive national program to prevent or reduce the mother-to-child transmission of HIV.

The national government and all the provinces apart from the Western Cape contested the case. At the time of the Court's decision in December 2001, the Western Cape had a policy of providing Nevirapine to HIV-positive mothers and their new-born babies. The policy had already commenced in January 2001 and by February 2002 was reaching 70 percent of women in the province. ${ }^{22}$ The new provincial government, formed by the NNP and the ANC in December 2001, with the premiership allocated to the NNP, did not result in a change of policy.

\section{THE FIRST LEGAL SKIRMISH}

The applicants contesting the national government's policy based their claim on the right to health-care services. They had to prove, among other things, that the government's failure to provide Nevirapine was not saved by the three qualifications to this socioeconomic right. They had to show that (1) the government was not taking "reasonable legislative and other measures," (2) there was no "progressive realization" of the right, and (3) it was "within available resources" of the provinces to do so.

A key part of the applicants' argument was that the Court could assess these elusive criteria by comparing the conduct of the eight provinces with that of the Western Cape. The latter province extended the provision of Nevirapine beyond the two test sites, and it was also rolling out a comprehensive plan that would cover all the women in the province by April 2003. Furthermore, this policy was within the Western Cape's “available

${ }^{21}$ Government of Republic of South Africa v. Grootboom, 2000 (11) BCLR 1169 (CC).

${ }_{22 “}$ All the president's provinces," Mail E Guardian, 22-28 February 2002, p. 7. 
resources." With all provinces receiving in excess of 96 percent of their revenue from intergovernmental transfers, it was not a case of rich versus poor provinces.

The High Court gave a judgment on 14 December 2001 fully endorsing this argument. The claim that there was no capacity in the public health sector to give effect to the right was dismissed with reference to the Western Cape's practice. ${ }^{23}$ The same answer was given regarding the fear that allowing doctors to prescribe Nevirapine would throw the system in disarray and cause budgetary distortions. ${ }^{24}$ The objections that a roll-out was not affordable was countered by the actual budget of the Western Cape.

The applicants succeeded in obtaining their requested relief. The Court ordered the national and provincial governments to make Nevirapine available to HIV-positive pregnant women and their babies in public hospitals having the necessary facilities and capacity. In devising a court order, the practice of the Western Cape was also influential. Nevirapine could be prescribed by doctors after consultation with the medical superintendant in charge of the health facility. ${ }^{25}$ On the second relief sought-getting a comprehensive and coordinated plan together for a roll-out of the programthe Western Cape practice was again the telling case. If the Western Cape could put together all the elements of a coordinated and programmatic plan, so could the other provinces. ${ }^{26}$

The national government and the eight provinces appealed against the decision to the Constitutional Court, the effect of which was to suspend the operation of the court order. Although no immediate relief was forthcoming, the success of the court case fuelled the public debate about the untenable national policy. The appeal itself was depicted as further evidence of heartlessness on the part of the government. Public sentiment eventually ruptured the united front of the eight provinces.

\section{PROVINCIAL DISSENT}

Widespread disquiet about the pilot-site policy was reported in many provinces. The IFP publicly instructed its KwaZulu-Natal premier, Lionel Mtshali, to distribute Nevirapine to all HIV-positive pregnant women in the province. ${ }^{27}$ In some provinces, doctors were, in defiance of national policy, providing the Nevirapine to HIV-positive pregnant women, often purchased from their own pockets. ${ }^{28}$ The talk was about a "spontaneous uprising" against the government's HIV/AIDS policy, with "the greatest success of the revolt" being the Gauteng government's decision to roll out its Nevirapine program.

${ }^{23} \mathrm{TAC}$ High Court judgment, 383F.

${ }^{24}$ Ibid., 383J.

sIbid., 384C

${ }^{26}$ Ibid., $385 \mathrm{C}$.

${ }^{27}$ Chief Mangosuthu Buthelezi's speech to Parliament, 14 February 2002, reported in "Buthelezi draws a line," Mail E' Guardian, 15-21 February 2002, p. 4.

${ }^{28}$ "Reality of Aids spurs widening revolt against government policies," Cape Times, 21 February 2002, p. 9. 


\section{Gauteng}

The most significant crack in the otherwise uniform ANC-governed provinces came when Gauteng broke ranks in 2002. That there was some disquiet in the ANC ranks was well known. Already, former President Nelson Mandela was critical of the government's approach to HIV/AIDS, only to be hauled in by the ANC leadership. ${ }^{29}$ Following a meeting between Mandela, President Thabo Mbeki, Deputy President Jacob Zuma, and other ANC officials, a decision was made that Mandela would not make any statements in his own personal capacity on the issue, but would speak about it only after first consulting with the ANC. ${ }^{30}$

Gauteng premier Mbhazima Shilowa, past Cosatu general secretary and referred to as the most "senior ANC premier," announced at the opening of the provincial legislature in February 2002 that Nevirapine would be made available to HIV-positive pregnant women at all public hospitals in Gauteng and large community centers within the next financial year. With a well-developed provincial health system, the program would be launched at seven hospitals within the next 100 days, and the rest would be provided for by the end of the financial year.

Whether Shilowa set out to defy national policy is not clear. There are some suggestions that he and his MEC for health were under the impression that, if the province had the capacity, it could go ahead and extend the provision of Nevirapine. ${ }^{31}$ The reaction of the national ministry of health suggests otherwise. Shilowa was accused of breaching resolutions adopted by the MECs at MinMECs that the roll-out of the Nevirapine program would only commence after research results at the pilot sites became available. A spokeperson for the ministry reportedly stated: "What is happening at Gauteng is against policy as stated in MinMEC. MinMEC now has to decide what, if any, action should be taken. Decisions made at MinMEC have been violated. But at this stage I do not know how the matter is going to be taken forward."32

As MinMEC is merely a consultative forum between the national government and the provinces, seeking to align policies and programs, there was nothing that this structure could do to get the Western Cape in tow or to sanction provinces that broke agreements. Any possible sanction lay within the political sphere. Instead of being asked to account to the MinMEC, Shilowa was lambasted by the ANC headquarters, being accused of political opportunism. ${ }^{33}$

Shilowa's stance had wide support. This was evident from the positive reaction by Cosatu and the SA Communist Party, which, with the ANC,

\footnotetext{
${ }^{200}$ Health minister slams Shilowa's Aids plan," The Star, 17 February 2001, p. 3.

so"Mbeki, Mandela meet to discuss Aids differences," Cape Times, 19 February 2002, p. 1

31“ANC closes ranks,” Mail E' Guardian, 22-28 February 2002, pp. 6-7.

${ }^{32 “ H e a l t h ~ m i n i s t e r ~ s l a m s ~ S h i l o w a ' s ~ A i d s ~ p l a n, " ~ T h e ~ S t a r, ~} 17$ February 2002, p. 3.

${ }^{834}$ "State in new bid to quell AIDS furore," Business Day, 22 February 2002, p. 1.
} 
formed the tripartite alliance fighting elections under the ANC banner. Cosatu came out in full support of the premier, and lambasted the national minister's stance. ${ }^{34}$ The SA Communist Party, more coyly, called for a meeting of the three partners for a full discussion on whether the present national policy was adequate. ${ }^{35}$ Shilowa's move could have been prompted by vocal disquiet voiced by his comrades in Cosatu on the government's HIV/AIDS policy, the emerging ambiguities around that policy, and the capacity of the province to commence with a roll-out plan.

The national Department of Health clearly lost the war. In response to the public spat, the national government took out a full-page newspaper advertisement stating that it was not against expanding the provision of anti-retroviral drugs to prevent mother-to-child transmission, but would not make it immediately available. Moreover, the appeal against the TAC High Court decision was not against the provision of Nevirapine, but "to gain clarity on whether the courts or elected government decides on the detail of providing health services. This is a critical question about the division of powers in our democracy." ${ }^{36}$

A political compromise was also struck with Shilowa; while there could be no talk of "the roll-out" of the program to all hospitals, Nevirapine could nevertheless be provided at additional sites in Gauteng. A national government statement read: "The new services are an expansion of the research programme and must be done in accordance with national guidelines and protocols." ${ }^{37}$ The crux of the national policy, the research sites, was not to be abandoned, but merely extended. Whatever the words, they did not hide the fact that Gauteng effectively changed the national "test site" policy.

\section{KwaZulu-Natal}

Less than a week after the Gauteng furor, the KwaZulu-Natal (KZN) IFP premier, Lionel Mtshali, announced that the province would provide Nevirapine to all pregnant mothers in the province; prior testing was not necessary because in rural areas, where there were no testing facilities, the incidence of HIV infection was the highest. ${ }^{38}$ Coupled with this announcement was the withdrawal of the KZN government as an appellant against the High Court decision and the joining of the TACapplication for the immediate enforcement of the decision. The problem was, however, that the provincial MEC responsible for health was a member of the ANC, and opposed to the TAC case.

\footnotetext{
34"'You're an embarrassment'," Cape Times, 20 February 2002, p. 1

${ }^{35}$ “SACP calls for alliance dialogue on nevirapine," Cape Times, 21 February 2002, p. 6; "Uneasy peace over HIV/AIDS policy shattered," Business Day, 20 February 2002, p. 1.

${ }^{364}$ State in new bid to quell AIDS furore," Business Day, 22 February 2002, p. 1.

${ }^{37 “ " N o ~ l i m i t s ' ~ o n ~ G a u t e n g ~ n e v i r a p i n e ~ p r o g r a m m e, " ~ C a p e ~ T i m e s, ~} 22$ February 2002, p. 3

${ }^{\text {sg }}$ "KZN jumps state Aids ship," Mail E' Guardian, 1-7 March 2002, p. 8. See also "Four KwaZulu hospitals to roll out nevirapine," Business Day, 28 March 2002, p. 2.
} 
As a footnote to the saga, a rather strange legal wrangle ensued that reveals much about coalition politics in South Africa. The KZN premier as head of the provincial government applied to the High Court to remove the province from the list of nine appellants and to join the TAC side. The provincial minister for health opposed this move, claiming that he still supported the national government's position. Thus, in the High Court, two different senior counsel appeared, each claming to represent the government of KZN. The High Court, correctly, ruled that the premier must prevail. The provincial MEC appealed the ruling to the Constitutional Court. ${ }^{39}$ The Constitutional Court, correctly, depicted the issue as follows:

\begin{abstract}
The real dispute is between the Premier and the MEC as to what stance should be adopted by the government of KZN in the TAC matter. Clearly this is a purely political dispute which could and should have been resolved at a political level. If the Premier was of the view that the MEC was not implementing the province's policy regarding the issues in the TAC case, he should have dealt with that at a political level..$^{40}$
\end{abstract}

Dealing with the matter at a political level means, in the Westminster system, the sacking of the MEC, a prospect that was politically not feasible in KZN. The coalition government in that province is not based on an agreement on policy but is a marriage of convenience where political parties place their own imprimatur on the departments they head. Facing this reality, the Court turned the application down on the erroneous ground that the two parties, both being organs of state, should have applied the principles of cooperative government and attempted to avoid litigation. ${ }^{4}$ By failing to comply with this duty, the Court thus refused the MEC's application for leave to appeal.

\title{
A CHANGE OF NATIONAL POLICY
}

On noting an appeal against the 14 December 2001 judgment, the legal effect was to automatically suspend the implementation of the court order. When applying for leave to appeal on 1 March 2002, the TAC counterclaimed for the immediate implementation of the court order. The High Court agreed to this. On 11 March 2002, it ordered that, pending the appeal to the Constitutional Court, Nevirapine should be given to HIVpositive pregnant women whenever possible. Against this order, the national government appealed to the Constitutional Court as well.

Having been recalled from recess, the Constitutional Court dismissed on 4 April 2002 the appeal against the execution order. ${ }^{42}$ The effect was

${ }^{{ }^{9} M E C ~ f o r ~ H e a l t h, ~ K w a Z u l u-N a t a l ~} v$. Premier of KwaZulu-Natal: In re Minister of Health and Others $v$. Treatment Action Campaign and Others 2002 (10) BCLR 1028 (CC).

${ }^{40}$ Ibid., para. 7.

"Nico Steytler, "The Settlement of Intergovernmental Disputes," Intergovernmental Relations in South Africa: Challenges of Co-operative Government, eds. Normal Levy and Chris Tapscott (Bellville: School of Government UWC \& PIMS, IDASA, 2001).

${ }^{424}$ Government is backed into corner after ruling," Business Day, 5 April 2002, p. 2. 
that the implementation order stood until the final outcome of the appeal on the merits. ${ }^{43}$ In compliance with the court ruling, pending the appeal on the main case, public hospitals that have the testing and counseling facilities must provide Nevirapine to patients who make an informed choice to use the drug.

The Constitutional Court's ruling must have sent a clear signal to the national government that the Court saw merit in the main case. On 17 April 2002, the national government announced a major reversal of policy, which entailed the embrace of anti-retroviral drugs as a valid form of therapy in the two areas of contention. First, victims of rape and sexual assault were to be given the option of anti-retroviral drugs. Second, the government was preparing the universal roll-out of Nevirapine for HIV-positive mothers from the end of $2002,{ }^{44}$ that is, when the 12 -month results from the pilot sites would be available. ${ }^{45}$ This change of face, a newspaper editorial commented, "was an admission of wrongness whose candour was rare even among the world's most established democracies." 46 The change in policy was attributed to pressures from a number of quarters. One commentator argued that "helping this [pressure] reach a critical mass is said to be the increasingly vocal unhappiness within the African National Congress and the government about the state's stance on HIV/AIDS." 7

Despite this about turn, the national government still pursued the court challenge on the question of principle-should courts decide policy?

\section{CONSTITUTIONAL COURT: FINDING NATIONAL POLICY WANTING}

After hearing argument in the beginning of May, the Constitutional Court handed down its judgment in July 2002. Noting that "[i]n our country the issue of HIV/AIDS has for some time been fraught with an unusual degree of political, ideological and emotional contention,"48 the Court sought to conduct a dispassionate and objective review of the national government's arguments and played down the different provincial policies and practices. Unlike the High Court, few direct references were made to provincial practices in considering the merits of the case, but when it came to devising a court order, the "dissident" provinces were, however, much in evidence.

On the first order-that Nevirapine be provided by all hospitals that have the capacity and facilities-the Court had to review the rationality of the national government's policy on Nevirapine. The government advanced four basic reasons for its policy. First, there were concerns about the efficacy

${ }^{49}$ Minister of Health and Others $v$. Treatment Action Campaign and Others (2), 2002 (10) BCLR 1075 (CC). 4" Government stages a dramatic about-turn on its AIDS policy," Business Day, 18 April 2002, p. 1; "Yes to Aids drugs for rape victim," Cape Times, 18 April 2002, p. 1.

${ }^{43}$ Belinda Beresford, "What bent Mbeki," Mail $\mathcal{F}^{2}$ Guardian, 19-25 April 2002, p. 3.

${ }^{46}$ "Let down by the 'hand of hope'," Sunday Times, 21 July 2002, p. 18.

${ }^{47}$ Beresford, "What bent Mbeki," p. 2.

${ }^{48}$ Minister of Health and Others $v$. Treatment Action Campaign and Others (1), 2002 (10) 1033 (CC), para. 20. 
of the drug if not accompanied by a host of other measures, such as counseling and formula milk. Second, the administration of the drug might lead to the development of resistance to the efficacy of the drug in later years. Third, there were safety concerns about the after-effects of the drug. Fourth, there was the question of whether the public health system had the capacity to provide the package of measures. This includes the costs of the drug, counseling, and the formula milk. In sum, the argument ran, without knowing the full extent of the costs and efficacy of the treatment, it would be unwise for government to commit itself to a wide-ranging program.

The Court found all these reasons unsubstantiated. The heart of the government's policy, according to the Court, lay in the fact that it was not practically or financially feasible to provide the program in each provincial hospital. The reason the Court dismissed this contention is because it disallowed the administration of the program in those hospitals (and provinces, implicitly) where there is the capacity to do so. ${ }^{49}$ Although there was no reference to the Western Cape, Gauteng, or KZN, the Court implicitly recognized that health services in South Africa are not monolithic; there would have to be an asymmetrical application of the program. It noted that the level of asymmetry in health-services provision is profound. On the number of fixed clinics offering HIV testing, provinces vary between 100 percent (Western Cape, Northern Cape, and Gauteng) to 14.6 percent in Limpopo with three provinces being between 40 percent and 53 percent (KZN 40 percent, Eastern Cape 44 percent, and North West 53 percent). On the number of fixed clinics offering HIV counseling, the differences are less, from 60.7 percent in Mpumalanga to 96.7 percent in Western Cape. ${ }^{50}$

The Court found that where counseling and testing facilities are available, it is well within the available resources of the state; "the provision of a single dose of Nevirapine to mother and child where medically indicated is a simple, cheap and poten tially lifesaving medical intervention." ${ }^{51}$ The Court thus held that the inflexible policy of only providing the drug at the 18 pilot sites was in violation of the Constitution's right to health-care services because it was not reasonable. ${ }^{52}$ Consequently, hospitals and clinics that have testing and counseling facilities should be able to prescribe Nevirapine where it is medically indicated.

On the second order-the roll out of a comprehensive plan-the issue was what role the Court should play when dealing with government policy. Having rejected the argument that judicial meddling with policy would be an infringement of the doctrine of the separation of powers, the Court reaffirmed its right to issue an injunction (or mandamus) and to exercise supervisory jurisdiction. ${ }^{53}$ However, having asserted the right to give an

49lbid., para. 64.

5oIbid., para. 90

s1 Ibid., para. 73 .

sqTbid., para. 80.

53Ibid., para. 106 
injunction, the Court still faced the question of how to compel a government with limited resources and capacity constraints-personnel and finances-to execute a policy. The question is thus whether budget constraints provide a legitimate reason for not implementing a comprehensive policy for the use of Nevirapine including testing and counseling. ${ }^{54}$

In answering this question, the Court made direct reference to provincial policy changes. It noted that when the application was launched in 2001, the policy was rigid. By the time of the argument on appeal in May 2002, flexibility had emerged in anti-HIV/AIDS policy. The Court referred to the Gauteng policy of extending the program to six hospitals and three community health-care centers and, during the course of 2002, throughout the province. ${ }^{55}$ The Court also mentioned "change in policy" in KwaZuluNatal. ${ }^{56}$ In the Court's view, " $[t]$ hese developments clearly demonstrate that, provided the requisite political will is present, the supply of Nevirapine at public institutions can be rapidly expanded to reach many more than the $10 \%$ of the population intended to be catered for in terms of the test site policy." ${ }^{57}$

The Court's view was, in effect, that where there is a will, there is a way, and that this axiom was amply illustrated by the conduct of some provinces. With such proof in hand, the Court could thus enter the terrain of policy with budget implications without much trepidation. The task at hand was thus to nudge the center to follow the "dissident" provinces. With reference to the fact that three provinces had adopted a program of extending the supply of Nevirapine throughout their territory, the Court depicted its role as that of facilitating the formation of the national political will. It said: "Government policy is now evolving. Additional sites where Nevirapine is provided with a 'full package' to combat mother-to-child transmission of HIV are being added. What now remains is for the other provinces to follow suit. The order that we make will facilitate this." 58

This passage reveals the Court's conception of the role and functioning of the decentralized polity. First, the reference to "government policy" sees national and provincial governments as a collective-"the government." From a Bill of Rights perspective, that is inevitable. The constitutional obligations imposed on the government cut across the national and provincial divide and provincial borders.

Second, the reference to the government policy that is "evolving" sees the political differences that gave rise to different policies in the first place as part and parcel of an evolutionary process that produces eventually a national policy. The result is that the national policy, enunciated by the Court, had its roots in the policies of the "dissident" provinces.

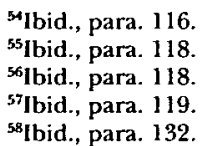


Third, the Court saw competitive politics as a part of an evolutionary process. It conveniently, and correctly, did not mention the political drama that constituted the evolution. There is no mention of the scuffle between the ANC and IFP politicians jostling to represent the province of $\mathrm{KZN}$ before it.

Fourth, the reasonableness of government policy is judged in the light of its constituent parts. Dissident provinces can show that the national policy is untenable while their own policy is feasible. Diversity of policy and practice meant that the Court was able to deal with the extremely difficult issues of budget and policy implications of enforcing socioeconomic rights. Spelled out much clearer in the High Court judgment, provincial differences became evidence of what content could be given to the requirement of "progressive realization" of socioeconomic rights. Likewise, existing provincial budgets gave an indication of what was "within its available resources" of the state.

\section{THE AFTERMATH}

The aftermath of the saga has been varied, but two events stand out. First, the outcome of the Constitutional Court case provided provinces with the scope to initiate innovative programs, and some seized the opportunity. The KwaZulu-Natal government applied to an international fund, the Global Fund to Fight HIV-AIDS, Tuberculosis and Malaria, for a R600 million grant that would fund the roll out of a comprehensive HIV/AIDS program in the province. The national ministry blocked the grant because all links with that international agency should procedurally have flowed through the national Department of Health. The dominant role of the national government in the field of international relations thus highlighted the limits of South Africa's decentralized system.

Second, courts may guide the direction of political will, but they do not necessarily create political will by judicial order. Implementation of the court order has been slow. Evidence emerged two months after the court judgment that some provinces were very slow in giving effect to the national policy, leading to charges of stonewalling the Court judgment. ${ }^{59}$ Where a provincial MEC is allegedly an adherent of the "dissident" scientific view on HIV/AIDS, ${ }^{60}$ the other side of the homogeneity debate may well come into play; how can new "dissident" provinces be brought into the national line? The processes mentioned above-financial incentives, political pressure, and if need be, national intervention-may follow. With national policy now part of a court order, contempt proceedings against dissenting provinces were mooted by the Treatment Action Campaign.

${ }^{594}$ Provinces stonewall action," Mail \& Guardian, 20-26 September 2002, p. 2; "TAC: We want to help," Mail E Guardian, 20-26 September 2002, p. 3.

60" TAC: We want to help," p. 3. 


\section{CONCLUSION}

The combination of the Constitutional Court judgment and the change in government policy has meant that all provinces have received national guidelines for the implementation of a prevention of mother-to-child transmission program. Training for a universal roll-out plan has also commenced in all provinces. ${ }^{61}$ A policy originating in one province, supported along the way by another two, became national policy. This case study is thus evidence that the formation of homogeneity in national policy is possible from the bottom up. What were the conditions under which this happened?

First, the fact that there is constitutional space for a province within which an innovative policy and practice can be developed was the key to the saga. However, whether the constitutional space is used depended in this case, at first, on opposition party politics. With the necessary political will, an opposition party in the Western Cape, supported by a strong health department, devised and implemented an innovative policy. In the other provinces, the national government, through the intergovernmental relations structure of the MinMEC on health, secured their compliance to adopt and implement the national policy.

Second, the impact of a province's innovative policy on the national policy was predicated on two processes-judicial and political-which, in this case, were tightly interwoven.

A civil-society organization (i.e., TAC) turned to the courts to enforce the socioeconomic right to health care across the nation. One province's innovative policy was used as evidence showing how other provinces were failing to comply with their constitutional obligations under the Bill of Rights. In the end, provincial policy and practice, which showed up the weakness of national policy, contributed significantly to the TACjudgments by illustrating the realms of the possible. The policy-laden and imprecise criteria-such as the "reasonableness" of policy, the time scales for "progressive realization" of socioeconomic rights, and the extent of "available resources"-which courts usually want to steer clear of, were made both comprehensible and manageable.

Despite the success of the TAC case, the judicial process usually provides a province with limited prospects of extending its policies to the national sphere. As long as the national government tolerates a competing policy in a province, the policy remains, perforce, restricted to its provincial location. Only where the national government translates its policy into legislation can a province contest it and, if successful, have a broader impact. The constitutional grounds on which national legislation may be challenged include (1) that the national government exceeded its override powers, ${ }^{62}$ 
or (2) the legislation is inconsistent with the Bill of Rights. Should a province's claim succeed, the court decision applies not only to the litigating province but to all the other provinces as well.

Given the limits of the judicial process, the political process remains critical. Where the innovative policy does not compete with a national one, political persuasion through the established intergovernmental relations structures is the obvious route and may lead to national acceptance. The sharing of new ideas to deal with old problems is part and parcel of the principle of cooperative government of assisting one another. However, where there are competing policies, the competition is usually fought along political lines.

Differences in policy can be used as a tool in political competition beyond the borders of a province. A successful innovative policy may advance the good-governance track record of a provincial party with national aspirations. An innovative provincial policy is then used to show up the weakness of the national policy and the consequences of the political decisions that underpin it. The feasibility and the moral superiority of the Western Cape's HIV/ AIDS policy compelled the other provinces and the national government, at a political level, to meet the case for the roll out of Nevirapine. While they could dismiss the Western Cape as an opposition maverick, civil society and public opinion saw the matter differently and sought to influence the national and provincial governments. Moreover, in the Niverapine case, the political and judicial processes became intertwined. The fact that the High Court found that the national policy was unconstitutional added fuel to the political debate. Appealing against the ruling became in itself a political cost for the national government. Within this context, the debate on Nevirapine moved beyond oppositional politics. Differences began to occur within the dominant political party that eventually erupted in the spat between the national Department of Health and the Gauteng province. It became apparent that provinces provided sites for political representation and contestation that were vulnerable to civil-society interventions.

Finally, this case study further illustrates how intergovernmental competition plays an important role in countering the tendency toward monopoly government that can be produced by cooperative government. The national government can, through the institutions of intergovernmental relations and in the name of cooperative government, effectively impose its policies on provinces. Competition in the field of policy establishes a counterweight and forms a sound basis for real cooperation where both the national government and provinces are seen and also act as partners in policy debates on matters of concurrent competence. 